\title{
The Diversity of Languages in the Alpine-Adriatic Region II. Linguistic Minorities and Enclaves in Austria and Western Hungary'
}

\author{
HerTa MAURER-LAUSEGGer \\ Institute of Slavonic Studies, Klagenfurt University, Austria
}

Die ethnischen Volksgruppen und kleinere Sprachgemeinschaften im multikulturellen Alpen-Adria Raum stellen seit jeher eine bedeutende Schnittstelle zwischen Sprachen und Kulturen mit vielfältiger Tradition dar. In diesem Raum befinden sich national homogene und national gemischte Gebiete. Zu den Minoritäten der Italiener, Kroaten, Österreicher, Slowenen und Ungarn, die in Mehrheits- und Minderheitssituationen leben, kommen noch die Gruppen der Roma und Sinti sowie die so genannten "neuen" Bevölkerungsgruppen aus dem südslawischen Raum (Bosnier, Kroaten, Serben u. a.), die sich in einigen Gebieten nach dem Zerfall des ehemaligen Jugoslawien angesiedelt haben. Sie alle stellen räumlich, politisch und sozioökonomisch ein Wesenselement dieser Region dar. Der vorliegende Beitrag behandelt die autochtonen slowenischen Minderheiten in Kärnten und der Steiermark, die Volksgruppen der Kroaten, Ungarn und Roma im Burgenland sowie die ethnischen Minderheiten der Ungarndeutschen, Kroaten und Roma im Komitat Győr-Moson-Sopron in Westungarn. Alle diese Minoritäten machten eine mehr oder minder gemeinsame geschichtliche und kulturelle Entwicklung durch, litten unter Diskriminierung, Verfolgung und Vertreibung, waren aber voneinander durch politische Grenzen getrennt. Die Rechte der Volksgruppen und kleineren Sprachgemeinschaften sind heute in nationalen und europäischen Gesetzen und Verordnungen verankert. Die Europäische Charta der Regional- oder Minderheitensprachen von 1992, der wohl bedeutendste Markstein für die Geschichte und Gegenwart der europäischen Sprachminderheiten, schaffte wichtige Grundlagen für den Schutz und Fortbestand von Volksgruppen und kleineren Sprachgemeinschaften. Durch die Öffnung der Grenzen und den europäischen Integrationsprozess sind nun verstärkte wechselseitige Kooperationen möglich. Die gegenseitige Unterstützung und Stärkung des

Tidsskrift for Sprogforskning, årgang 6, 2008

Århus: Statsbiblioteket

Artikel nr. 1, Maurer-Lausegger, Herta, 39 pp.

http://ojs.statsbiblioteket.dk/index.php/tfs/index 


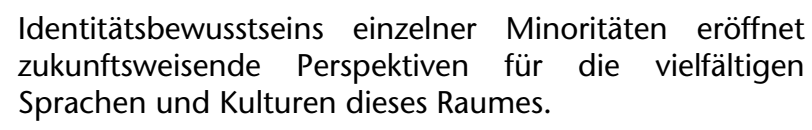

\section{INTRODUCTION}

One characteristic of the Alpine-Adriatic region is the large number of ethnic minorities and smaller speech communities (language islands) with long and varied traditions. These groups have always played an important role as bridges between the languages and cultures of Europe. The region lies in Central Europe, at the point where the Germanic, Slavonic and Romance cultures meet and where there are no clear borders between ethnicities. Nationally homogeneous and mixed areas exist side by side: people speaking Austrian German, Slovene, Croatian, Hungarian and Italian live here both as majority and minority groups. In addition there are groups of Roma and Sinti, concentrated in a few areas, and the so-called "new" groups from the southern Slavonic region (Bosnians, Croatians, Serbs, etc.) who settled in the Alpine-Adriatic region after the collapse of Yugoslavia. Despite all this linguistic and cultural variation, the local vernaculars in smaller enclaves are particularly under threat of disappearing forever. The reasons for this development are many and varied, and go beyond the scope of this paper, but globalization and the loss of functionality in everyday communication are certainly major threats to the survival of regional vernaculars (cf. Maurer-Lausegger 2006a: 325f).

The ethnic minorities in the Alpine-Adriatic region ${ }^{2}$ are divided up amongst the regions of northern Italy, Austria, Hungary, Slovenia and Croatia as follows:

\section{Northern Italy \\ The German ethnic group in South Tyrol, the ethnic groups of Germanic origin in the province of Trentino (the Ferina valley, Lusern) and in Friuli (Sauris, Timau, the Canale valley); the Ladin ethnic group (in the provinces of Bolzano, Trentino and Belluno); the Friulians (in the region of Friuli- Venezia-Giulia); the Slovenes (in the provinces of Udine, Gorizia and Trieste in the region of Friuli-Venezia-Giulia).}

\section{Austria}

The Slovene ethnic groups in Carinthia and Styria; the Croatian and Hungarian ethnic groups and the ethnic group of the Roma in Burgenland. 


\section{Slovenia}

The Italian ethnic group (Istria); the Hungarian ethnic group (in Slovene-Hungarian border areas in the Prekmurje region); the ethnic group of the Roma.

\section{Croatia}

The Italian, Hungarian, Czech and Slovak ethnic groups; the Russinian and Ukrainian minorities and the ethnic group of the Roma.

Hungary (minorities in the counties covered by the Alpine-Adriatic Association)

The German, Croatian and Slovene minorities as well as the ethnic group of the Roma.

(Maurer-Lausegger 2006a: 325f; translated by HML; cf. Minderheiten 1990, Minderheiten 2004)

The ethnic minorities mentioned above are an essential characteristic of the political, social and economic reality in the Alpine-Adriatic region. ${ }^{3}$ Indeed, the people living in these areas have experienced more or less the same history and culture, and are linked both economically ${ }^{4}$ and linguistically although divided by political borders (cf. Rumpler 2001: 567). As Klemenčič notes, the attitude of these states towards their national minorities varies, depending on sociopolitical circumstances, and is affected by developments in both rural and industrialized areas as well as by the gradual opening up of national borders (cf. Klemenčič 1994: 6; Maurer-Lausegger 2006a: 326).

This paper will deal with the ethnic minorities in the Alpine-Adriatic areas of Austria and Western Hungary.

\section{ETHNIC MINORITIES IN AUSTRIA}

Officially recognized autochthonous ethnic minorities live in five Austrian provinces: the Slovenes in southern Carinthia (in the Gailtal, Rosental and Jauntal valleys as well as in the Obir region), the Slovenes in Styria (in some villages along the Austrian-Slovene border) and the Croatians, Hungarians, Roma and Sinti in Burgenland, many of whom have migrated to Vienna. ${ }^{5}$ Alongside these ethnic minorities there are the ethnic groups of the Roma and Sinti who were not officially recognized as such until 1993. Most of them live in Burgenland and Vienna but a few also live elsewhere.

(cf. Volksgruppenreport 2001; http://www.demokratiezentrum.org). 
Since 1986 all recognized ethnic groups in Austria have had an umbrella organization to represent their interests, known as the Austrian Centre for Ethnic Groups (Österreichisches Volksgruppenzentrum), with the Austrian Committee of the European Bureau for Lesser-Used Languages (Österreichisches Komitee des europäischen Büros für Sprachminderheiten), which is based in Vienna (cf. http://www.nsks.at/aktuelles.php).

I would now like to take a closer look at the minorities living in the AlpineAdriatic region within Austria, in other words in the provinces of Carinthia, Styria and Burgenland. Legal regulations covering the language use of the Slovene and Croatian minorities in the three provinces are established in Article 7 of the Austrian State Treaty (Federal Law Gazette No. 152/1955) (Artikel 7 des Staatsvertrages von Wien, BGBl. Nr. 152/1955).

Austrian citizens belonging to these minorities have the same rights on equal terms as all other Austrian nationals. They are guaranteed primary schooling in their mother tongue and a proportional number of secondary schools. They are entitled to the use of Slovene or Croatian as an official language, and bilingual topographical terminology and inscriptions, etc. ${ }^{6}$ Further rights for these minorities are protected by the Federal Law on the Legal Position of Ethnic Groups in Austria, known as the Ethnic Groups Act (Federal Law Gazette No. 396, in the version announced in Federal Law Gazette Nos. 575/1976 and 24/1988) (Bundesgesetz über die Rechtsstellung der Volksgruppen in Österreich (Volksgruppengesetz), BGBl. Nr. 396, in der Fassung der Kundmachungen BGBl. Nr. 575/1976 und 24/1988). ${ }^{7}$

\subsection{The Slovene Ethnic Groups in Carinthia and Styria}

In Austria there are two autochthonous Slovene minorities: a larger ethnic group in the province of Carinthia and a smaller one in neighbouring Styria.

\subsubsection{The Slovene Ethnic Minority in Carinthia}

The bilingual area in which Slovene-speaking Carinthians live has had an autochthonous Slovene-speaking population since the $6^{\text {th }}$ century. The local Slavic rulers of Carantania, as Carinthia used to be called, were deposed by Frankish settlers in 820 and since then the area has been dominated by the German population in political, economic and cultural terms. In around 1500, once medieval colonization had been completed, the language border between 
German and Slovene started to become more clearly defined, running from Hermagor/Šmohor in the Gailtal valley via Villach/Beljak, Köstenberg/Kostanje and along the northern shores of Lake Wörthersee to Maria Saal/Gospa sveta and Diex/Djekše before continuing to Lavamünd/Labot in the east of Carinthia. ${ }^{8}$

In 1846, two thirds of the province spoke German while south of the language border, Slovene speakers made up around 84 percent of the population (cf. Lukan 1979: 84). In this area, only the nobility spoke German, along with some of the inhabitants of larger towns, but this did not have much influence on the much larger Slovene-speaking rural population (cf. Grafenauer 1984: 13f). In the agricultural feudal society at that time, nobody thought in terms of ethnic/national categories (cf. Fräss-Ehrfeld 2000: 26).

According to Reiterer, the Slovene-German language border developed into one of the burning issues of national conflict in the late Hapsburg monarchy. It kindled the flames of the cultural contest between Catholicism and liberalism, which overlapped with the main conflict concerning the language of instruction to be used in schools (cf. Reiterer 2004: 182). As Domej points out, the German speakers assigned themselves the role of upholders of the Enlightenment, transmitters of culture, pioneers of progress and upholders of the state, both in mental and propagandistic terms. In this context, an active policy of assimilation fitted in well (cf. Domej 1999: 262). Influenced by socioeconomic and political factors, German continued to strengthen its hold on the area, increasing in intensity in the second half of the $19^{\text {th }}$ century and even more so in the $20^{\text {th }}$ century.

In the nationalist age of the $19^{\text {th }}$ and $20^{\text {th }}$ centuries, a second group of Slovene speakers evolved in Carinthia, the so-called "Windisch" people. They did not consider themselves to be Slovenes and yet were not German either as they could not speak the language very well. The concept of the "Windisch" became a useful ideological tool because they only existed as a group by definition of their supposed ethnic affiliation (cf. Moritsch 1995: 15; Maurer-Lausegger 2006b: 181). Slovene speakers who held onto their Slovene origins after the collapse of the Hapsburg monarchy ran the risk of being branded renegades, while those who professed themselves to be German or declared themselves as "Windisch" were considered to be loyal to their native land (cf. Rektorenkonferenz 1989: 
64). However, the importance of the "Windisch" diminished rapidly in the course of the $20^{\text {th }}$ century. ${ }^{9}$

Still, there were major social differences between the dominant and evergrowing German-speaking population and the subordinate Slovene speakers in rural Carinthia. Under pressure to assimilate, the proportion of Slovene speakers decreased still further and the language border shifted farther to the south and southeast of the province. The latest official figures, taken from the 2001 census, show that only 14,010 people gave Slovene as the language they used in everyday life (http://www.statistik.at).

Over the centuries, Carinthia has experienced eventful times which still leave their mark on the linguistic and mental profile of the population today. The subordinate role of Slovene in Carinthia is reflected in the relationship between the two languages. The symbiosis between them varies diatopically, which means that the differences are conditioned by geographical factors, and diastratically, which means that there are differences in terms of social strata (cf. Hafner 1985: 47). Indeed, there is an extraordinary variety of dialects and vernaculars in the bilingual regions of Carinthia. The older bilingual population in rural areas tends to continue using their Slovene vernacular, as long as it is appropriate in the sociolinguistic situation, while in many parts of the bilingual region, particularly on the northern German-Slovene language border, the younger generation has already switched over to speaking German (cf. MaurerLausegger 1994a, Maurer-Lausegger 1994b). In contrast with the Burgenland Croatians, who have developed a written language of their own, the Carinthian Slovenes use standard Slovene as their written language.

One dilemma faced by the Slovene minority is the migration of large numbers of bilingual speakers from rural to urban areas for socioeconomic reasons. At the same time, people who speak German, and also other languages (e.g. Bosnian, Croatian, Serbian), are moving into the bilingual areas. The presence of nonSlovene speakers in a village encourages the more rapid adoption of German for everyday communication so that what used to be dominant Slovene vernaculars are severely losing out on functionality in situations of daily life (cf. MaurerLausegger 2008: 67). 
The Carinthian Slovenes have their own political, academic and cultural organizations, including local cultural associations, music and folklore groups and choirs. Bilingual and multilingual educational institutions are partially guaranteed by Article 7 of the Austrian State Treaty of 1955 (kindergartens, primary and secondary schools). As for media, there are various transregional and local newspapers; Slovene radio programmes are broadcast by the Austrian Broadcasting Company's Carinthian studio and on a private frequency; and there is a half-hour TV programme in Slovene which is broadcast every Sunday all over Carinthia (http://volksgruppen.orf.at/slowenen). Yet the majority language German dominates in most bilingual areas despite a wide range of opportunities to use Slovene (cf. Maurer-Lausegger 2008: 67).

There are several umbrella associations covering socio-political aspects of Carinthian Slovene life. Set up in 1949, the Council of Carinthian Slovenes (Narodni svet koroških Slovencev / Rat der Kärntner Slowenen, http://www.nsks.at) sees itself as the representative of the political, economic and cultural rights and interests of Slovene speakers in Carinthia (cf. Anderwald 2004: 179). The second political organization, the Association of Slovene Organizations (Zveza slovenskih organizacij / Verband slowenischer Organisationen, http://www.slo.at) has been around since 1955 and is multicultural in its views, for example it is not in favour of creating an independent party just for the Slovenes (cf. Anderwald 2004: 179). In the course of discussions about an organization to represent the interests of all Carinthian Slovenes, a third organization was set up in 2003, namely the Association of Carinthian Slovenes (Skupnost koroških Slovencev in Slovenk / Gemeinschaft der Kärntner Slowenen und Sloweninnen, http://www.skupnost.at). It strives for dialogue between members of the Slovene ethnic group in Carinthia as well as a joint, democratic, pluralistic representation of all Carinthian Slovenes (http://www.skupnost.at/1de/statut/fs_statut.htm). The transregional Unity List (Enotna lista / Einheitsliste), which emerged from the Association of Slovene Councillors (Klub občinskih odbornikov / Klub slowenischer Gemeinderäte) in 1991, is campaigning for a legally guaranteed mandate for a representative of the Slovene ethnic group in the Carinthian parliament (cf. http://www.elnet.at), together with the Council of Carinthian Slovenes. 
The central interface between Slovene speakers and local government in Carinthia is the Office for Ethnic Minorities at the Carinthian Provincial Government (Volksgruppenbüro beim Amt der Kärntner Landesregierung / Biro za slovensko narodno skupnost pri Uradu Koroške deželne vlade, http://www.volksgruppenbuero.at), established in 1990, which should enable and facilitate better communication between members of the ethnic group or their organizations and the administration within Carinthian local government. In order to encourage the use of Slovene as an official language, application forms in Slovene are available online for official documents such as passports, identity cards, driving licences, certificates of registration, fishing and hunting permits. ${ }^{10}$ However, not many Slovenes take advantage of these services. In fourteen officially recognized bilingual communities in southern Carinthia, Slovene can also be used as an official language on request. The legal regulations do, however, differ. There are certainly problems with Carinthian bilingualism caused by sociolinguistic and political factors but it is not possible to discuss them here. ${ }^{11}$

Carinthian Slovenes have two central Cultural Associations: the Slovene Cultural Association (Slovenska prosvetna zveza / Slowenischer Kulturverband, http://www.slo.at), reconvened in 1945 after the Second World War, and the Christian Cultural Association (Krščanska kulturna zveza / Christlicher Kulturverband, http://www.kkz.at). The second umbrella association was set up in 1949 after it had split off from the first on grounds of ideological differences. The two associations, which have been cooperating very well with each other in recent years, represent around sixty local cultural associations (cf. Volksgruppenreport 1997: 91-95).

Slovene is also present in the public sphere in Carinthia, in the church, and business world, for example. The liturgy is celebrated in German and Slovene in many bilingual congregations. In fact, the church has always played a very important role in maintaining the use of Slovene.

\subsubsection{The Slovene Minority in Styria}

Slovene-speaking Styrians live in the districts of Leibnitz, Deutschlandsberg and Radkersburg in the Austrian part of Styria, as well as in Graz, the capital of the province. Most of them live in the area known as the "Radkersburger Winkel" in 
the southeasternmost part of Austria (cf. Križman 1996: 168; Volksgruppenreport 1997: 162 f).

Slavic settlement began there in the $6^{\text {th }}$ century. From the $9^{\text {th }}$ century to the $13^{\text {th }}$, land was acquired by Bavarian colonizers (cf. Gril/Hadler/Hammer 2006: 123). In 1278 the Duchy of Styria became part of the House of Hapsburg. The northern part, Upper Styria, was German-speaking and the southern part Slovenespeaking. Since the $15^{\text {th }}$ century, the border between the languages has been more or less identical with the course of the River Mur. When the Hapsburg monarchy collapsed in 1918, Lower Styria became part of Slovenia (cf. Križman 1996: 171).

In comparison with the Carinthian Slovenes, Slovene speakers in Upper Styria are a repressed minority (cf. Stenner 1997) which has always been under pressure to assimilate, but particularly since the mid $19^{\text {th }}$ century. This is one reason why the Styrian Slovenes never developed a national sentiment. The First World War marked a historical caesura as centuries of coexistence between Slovene and German speakers came to an end: after the borders were redrawn in 1919/1920, contacts between the two language groups mostly ceased, and with that their common history, resulting in missed opportunities and affecting the whole issue of existence and development (cf. Križman 1997: 35). This split clearly left its mark on the population. After the so-called "Abwehrkampf" to oust Yugoslav troops who had occupied Austrian territory in border regions in 1918-19, Austrian Slovenes found themselves living in an unambiguously Germanspeaking country, and particularly so in Styria. This led to increased assimilation and the displacement of Slovene from public life. The urge to forget and suppress still remains to this day (cf. Gril/Hadler/Hammer 2006: 124 and 126).

From a legal point of view, the Slovene speakers in Styria are disadvantaged in comparison with other linguistic minorities in Austria. Article 7 of the Austrian State Treaty of 1955 was not put into effect until very late: the Styrian Slovenes were not recognized as an autochthonous minority until 2004. Since 1994 they have been represented on the Austrian government's Ethnic Groups Advisory Board (Volksgruppenbeirat) and gained the right to vote once they were officially recognized. In the 2001 census, 4,250 Styrians declared themselves as Slovene speakers. ${ }^{12}$ 
Nowadays the chances for Slovene speakers in Styria to create their own Slovene identity are quite poor as Slovene is only used to a very limited extent in the immediate family, and many speakers are not very competent in their use of the language (cf. Križman 1996: 182). Members of the minority living in and around Radkersburg generally do not consider it necessary to learn standard Slovene in order to communicate. The regional dialect of Slovene spoken there is understood on both sides of the border, even though it is restricted and shows many elements of interference (cf. Križman 1997: 35). In contrast to German speakers, who have all the different forms of German at their disposal from the standard language to their southern Styrian (south Bavarian) vernaculars, bilingual speakers are disadvantaged, not least because a lack of Slovene schools means that bilingualism is not nurtured in the educational system and standard Slovene is not passed on. Thus the dialect form of Slovene is faced with all the forms of German (cf. Križman 1996: 174). In fact there are only very few schools in southern and southeastern Styria where Slovene is offered as an elective (cf. http://www.pavelhaus.at/publikationen/signal00 deutsch/signal00 02.htm).

The linguistic situation in the last few Slovene language islands in Styria gives cause for alarm. Young people, most of whom only understand a few words of Slovene, have swapped over entirely to German and no longer consider themselves as members of a linguistic minority (cf. Gril/Hadler/Hammer 2006: $125)$.

However, positive developments for the Slovene minority in Styria have been achieved by Pavel's house (Pavelhaus/Pavlova hiša) in Laafeld/Potrna near Radkersburg, which is envisaged as an intercultural centre and meeting place for German and Slovene speakers. The cultural association Article VII (Artikel VIIKulturverein für Steiermark / Kulturno društvo člen 7 za avstrijsko Štajersko) deals with all aspects of minority issues in fulfilment of Article 7 of the Austrian State Treaty of 1955, organizing cultural and academic events, putting on exhibitions and supporting the use of Slovene in schools. It also publishes a bilingual newspaper called Signal (launched in 1989). Since 1 May 2004, a permanent exhibition has been on display there which covers the topics of Slovenes in the Austrian part of Styria, Roma in Slovenia and German speakers in Slovenia. ${ }^{13}$ 


\subsection{The Croatian, Hungarian and Roma Ethnic Groups in Burgenland}

In Austria's easternmost province, Burgenland, Croatian, Hungarian and Roma minorities live alongside the German-speaking population. Burgenland became the ninth province in the Republic of Austria in 1921; up to 1920 this area had been part of Hungary and Hungarian was the official language (cf. Jodlbauer 1996a: 83; Neweklowsky 1996: 2).

\subsubsection{The Burgenland Croatians}

"Burgenland Croatian" refers to the Croatian-speaking population of Burgenland in eastern Austria as well as to all Croatian-speaking inhabitants of Austria, Hungary, Slovakia and the Czech Republic whose ancestors were relocated from areas in Croatia and northwestern Bosnia to the Austrian-Hungarian-Slovak border regions for economic reasons in the $16^{\text {th }}$ century (Neweklowsky 1978: 19; Robak 1985: 15). The areas of western Hungary, Lower Austria and southern Moravia in which they settled were suffering from a great shortage of agricultural workers in the wake of the medieval agrarian crisis and high death tolls from the plague (1408/09) (cf. Neweklowsky 2006: 2). According to Ivancsics, several lords of the manor in western Hungary also had property in areas of Croatia and Slavonia threatened by the Turks. It made sense to repopulate their deserted estates with subjects from Croatia (cf. Ivancsics 2004: 65; Robak 1985: 17). The Croatian immigrants came from the interior of the country, between the Kupa, Sava and Una rivers, which was Cakavian at the time, as well as from western Slavonia and northwest Bosnia (cf. Neweklowsky 2006: 2). ${ }^{14}$ There were two main waves of settlement in Burgenland, from 1533 to 1545 and from the 1560 s to 1570 s. In around 1600 some $25-28$ percent of the population was estimated to be of Croatian descent while the Hungarians only added up to between 5 and 7 percent. It is assumed that around 90 percent of the Croatians were involved in agriculture (cf. Ivancsics 2004: 65).

During the $16^{\text {th }}$ and $17^{\text {th }}$ centuries there were several rebellions by the Hungarian-speaking population against Hapsburg rule as well as invasions of the Turks. From the $18^{\text {th }}$ century onwards, the area was marked by the suppression of both the German and Croatian farming communities by the ruling Hungarian high nobility. As Jodlbauer pointed out, once the popular revolt of 1848 had been suppressed in Hungary, attempts were made to magyarize Burgenland. German and Croatian traditions were suppressed and German was replaced by 
Hungarian, even in schools (Jodlbauer 1996a: 83). Starting in 1867, there was a policy of enforced assimilation of the non-Hungarian sections of the population in the area of Burgenland-western Hungary. The authority of the state was exploited to favour those who traditionally spoke Hungarian or had changed over to speaking Hungarian, resulting in the domination of the Hungarian minority in this area to the disadvantage of the Croatians (cf. Reiterer 1990: 47).

Before 1921, the contacts between Croatian and Hungarian were much closer than between German and Burgenland Croatian (Jodlbauer 1996a: 84). However, in the process of drawing up the border between Austria and Hungary, 15 Croatian-speaking villages were left on the Hungarian side, which noticeably weakened the Croatian minority in Burgenland (cf. Ivancsics 2005: 66).

The areas in which the Burgenland Croatians settled were never contiguous and are now divided up over six out of the seven administrative districts in Burgenland, in the form of language islands, in a total of 48 villages (cf. Ivancsics 2004: 67).

Today, around 15 percent of the total population in Burgenland are bi- or multilingual. All in all, 24 percent are directly affected by multilingualism, either because they themselves are multilingual or because they live with a partner who is multilingual (cf. Ivancsics 2004: 69). Estimates of the size of the Croatian ethnic group vary, up to a maximum of 30,000 members. Official statistics dating from 1991 mentioned 19,109 (7.3 percent) Croatians (cf. Ivancsics 2004: 69), while in the most recent census in 2001 only 16,283 declared themselves as Croatians. ${ }^{15}$

Burgenland Croatian is characterized by a great number of dialects and vernaculars which have already been described in numerous monographs (e.g. Neweklowsky 1978, Koschat 1978, etc.). Now being used in the educational system, it is beginning to develop a standard version but in comparison with the German majority language, it does not represent a polyvalent standard language which could fulfil all functions in public and private life (cf. Neweklowsky 2006: 7). Thus, inasmuch as they speak Croatian, the Croatians in Burgenland use the dialect spoken in their village to communicate but use of Croatian is mostly limited to everyday situations within the family and in the village (Jodlbauer 
1996a: 115). As Szucsich explains, due to social and institutional conditions, in those areas with a Burgenland Croatian population, original asymmetrical bilingualism to the disadvantage of German or Hungarian has changed radically since the turn of the century to the detriment of Burgenland Croatian (Szucsich 2000: 874).

Linguistic interference is becoming increasingly frequent. In those villages which were predominantly Croatian-speaking between the two World Wars, a powerful process of assimilation is now taking place and has, in fact, already been completed in the generation under 20 in the villages of northern and southern Burgenland. ${ }^{16}$

As far as written texts are concerned, they used to be strongly influenced by the particular dialect on which they were based. Before the language was standardized and codified, a Burgenland koine already existed, yet its norms did not have a firm foundation and many variations were permissible. Literary texts from the $19^{\text {th }}$ century and first two thirds of the $20^{\text {th }}$ were not very standardized but served as a basis for the early stages of codification. However, starting in the 1970s, plans to develop a written language of their own for Burgenland Croatians have been carried through. As Völkl points out, in contrast to the Carinthian Slovenes, the Burgenland Croatians decided against adopting the modern written language of the country they originally came from, in an endeavour to preserve their identity, resolving instead to take their own linguistic tradition as a basis for their written language (Völkl 2000: 60). The foundation for this common written language is the Cakavian dialect which is influenced by standard Croatian (in Croatia). The linguistic relationship between Croatian and Burgenland Croatian has not been conclusively clarified (cf. Marti 2000: 537). Despite the best of intentions, both spoken and written Burgenland Croatian has remained highly heterogeneous (cf. Szucsich 2000: 874).

There are several cultural, academic and political associations for Croatian speakers in Burgenland. The Burgenland-Croatian Centre (Burgenländischkroatisches Zentrum / Gradišćansko-hrvatski Centar, http://www.hrvatskicentar.at) is an intercultural institution which encourages cooperation between associations and institutions in Austria and abroad. Two associations run this centre, the Croatian Academics Club (Kroatischer 
Akademikerklub / Hrvatski akademski klub) and the Burgenland Croatian Cultural Association in Vienna (Burgenländisch-Kroatischer Kulturverein in Wien / Hrvatsko gradišćansko kulturno društvo $u$ Beču, (cf. http://www.hrvatskicentar.at/deutsch/default.htm).

The Academic Institute for Burgenland Croatians (Wissenschaftliches Institut der Burgenländischen Kroaten / Znanstveni institut gradišćanskih Hrvatov, http://www.zigh.at) takes care of linguistic matters and issues an academic magazine online, amongst other things. There is a Croatian Press Association, a Croation Cultural and Documentation Centre, an adult education centre (since 1984) and other institutions. The Croatian Press Association publishes books, a weekly newspaper entitled Hrvatske novine (Croatian News) and an annual calendar with literary and popular science articles. The church publishes a Croatian newsletter, the Crikveni glasnik Gradišča (Church messenger for Burgenland), which is the second weekly paper in the province. On a cultural level, tamburica, folklore and amateur theatre groups are very popular (cf. Ivancsics 2004: 80; Jodlbauer 1996a: 82).

Schooling is bilingual. The Burgenland Education Act dating from 1937 (Burgenländisches Landesschulgesetz 1937, Bgld. LGBl. 40), which was actually seen as an exemplary solution in that day and age, was replaced by the new Minority Schools Act for Burgenland in 1994 (Provincial Law Gazette No. 202/1994) (Minderheitenschulgesetz für das Burgenland, Bgld. LGBl. 202/1994). This ensured that primary schooling in autochthonous areas was bilingual as a matter of principle, with German and Croatian both taught as subjects. Since the new curriculum was introduced in 1998, teaching can be organized along more flexible lines. In contrast with primary schooling, pupils at the nine secondary modern schools in the area have to actively sign up for Croatian lessons (cf. Ivancsics 2004: 67 and 78f). In 1989, the Kindergarten Act for Burgenland (Novelle zum Burgenländischen Kindergartengesetz 1989, Bgld. LGBl. 7/1990) was passed by the Provincial Government, guaranteeing bilingual supervision at kindergartens. Since 1991 there has been a bilingual grammar school in Oberwart/Borta where teaching either takes place in a combination of Croatian and German or Hungarian and German. Croatian is also offered in various forms at seven other secondary schools (cf. Ivancsics 2004: 79). At 
university level, language courses for Burgenland Croatian are offered at the Universitiy of Vienna.

In 1987 Burgenland Croatian was recognized as the second official language in Burgenland in accordance with a decision passed by the constitutional court. This also improved the standing of Burgenland Croatian in the media, particularly within public-service television and radio (ORF). In 1979 Croatianlanguage editorial offices were set up in the ORF's Burgenland studio which is now responsible for producing 42 minutes of radio programmes every day except Sundays. Since 1 April 1989 a Burgenland Croatian TV programme, entitled "Dobar dan, Hrvati" (Good Morning Croatians), has been broadcast on Sundays, lasting just 20 minutes to start with and then extended to 30 minutes in 1990 (http://volksgruppen.orf.at/kroatenungarn; cf. Volksgruppenreport 1997: 110 ).

In 1994 a private radio station, called MORA, was founded. It has been broadcasting on local frequencies concentrating on multicultural programmes in minority languages, i.e. Croatian, Hungarian and Roman (cf. Volksgruppenreport 1997: 111).

Burgenland is an economically weak area, which makes it necessary for many to commute to Vienna and other towns or even move there permanently: around 8,000 Burgenland Croatians live in Vienna, for example (cf. Ivancsics 2004: 68). The fall in the number of Croatians living permanently in Burgenland also creates disadvantages for the minority. However, due to the geographical proximity and the flourishing cultural and political activities of Croatian associations and organizations in Burgenland and Vienna, it is possible to continue to support the interests of the Burgenland ethnic group.

\subsubsection{The Hungarian Minority in Burgenland}

Together with Finnish, Hungarian belongs to the Finno-Ugric group of languages which in turn belongs to the family of Uralic languages. ${ }^{17}$ Starting in the $10^{\text {th }} / 11^{\text {th }}$ centuries the territory of modern-day Burgenland was settled from the east to mark the Hungarian border. During the reign of the Hapsburg monarchy, Burgenland belonged to the Hungarian part although a large majority of the population spoke German. However, within Hungary itself, both 
German and Croatian speakers were a minority compared to the Hungarian speakers (cf. Reiterer 1990: 51).

After Burgenland became part of Austria, quite a large proportion of the Hungarian population left (1920-21). However, the failed Hungarian uprising in 1956 resulted in large numbers of Hungarian refugees arriving in Burgenland, many of whom then settled there (Jodlbauer 1996a: 84). Official statistics from 1991 show that 4,973 members of the Hungarian minority lived in Burgenland (Wöbking 2000: 86). The latest official figures, taken from the 2001 census, show that 6,641 declared themselves as Hungarian speakers (http://www.statistik.at). Unofficial estimates give the number at around 14,500, which is about 5.3 percent of the total population of the province (cf. Ivancsics 2004: 69).

The Hungarian language was not recognized by law in Burgenland until the Ethnic Groups Act (Volksgruppengesetz von 1976) was passed in 1976. Today there is bilingual German-Hungarian education in kindergartens, primary schools and secondary modern schools as well as at the bilingual grammar school in Oberwart and in the so-called "Pannonian" class at the grammar school in Oberpullendorf. Hungarian can also be taken as an elective at other schools (cf. Wöbking 2000: 87; Volksgruppenreport 1998: 33).

In Burgenland only very modest provision is made for Hungarian-language media. Since 1987 a 25-minute radio programme has been broadcast daily in Hungarian, and since 1989, a half-hour TV programme has been broadcast six times a year on the regional TV channel. Just like the other minorities, the Hungarians in Burgenland also have their own institutions, educational establishments, organizations and associations. ${ }^{18}$

\subsubsection{The Roma in Burgenland}

Six Romany subgroups live in Austria: the three autochthonous groups of Burgenland Roma, Sinti and Lovara, who enjoy minority rights in accordance with the Ethnic Groups Act, and the three non-autochthonous groups of Kalderaš, Gurbet and Arlije (who came to Austria to work in the 1960s), to whom minority rights in accordance with the Ethnic Groups Act do not apply (cf. Volksgruppenreport 1997: 149-155; Volksgruppenreport 1998: 39-42). There are differences between the various groups. "The Austrian Roma population is 
heterogeneous in many respects: the groups differ from each other in their sociocultural background, their current socio-political status [...]" (Halwachs 2004a: 1 and 7). The Roma who live in the region where Austria, Slovenia and Hungary meet are known as the Vend group, primarily on linguistic and other grounds (cf. Halwachs 2004a: 7; Info-Blatt 2004: 3).

It was around 1000 years ago that the Roma set off on their long journey from India to Europe, at a time when most Europeans already led a relatively settled lifestyle. They came via Turkey to settle in the Balkans, some of them moving on as far as North Africa and Spain. Other subgroups, such as the Sinti, Lovara and Kalderaš were also part of this mass migration. The non-sedentary lifestyle of the newcomers and their foreign-looking appearance were not well received and the Roma were often subject to persecution and discrimination. Those who were not considered to be of any use by the local powers were persecuted and often executed (cf. Gärtner-Horvath 1999: 9).

The Roma were first mentioned in western Hungary and modern-day Burgenland at the end of the $14^{\text {th }}$ century. At the beginning of the $15^{\text {th }}$ century, largish groups moved into the western Hungarian-Pannonian region, among them the ancestors of today's Roma (cf. Halwachs 2004a: 1), musicians, armourers and blacksmiths who accompanied the Turkish army (cf. GärtnerHorvath 1999: 9). One characteristic of the Roma who settled at the western limits of the sphere of Hungarian influence, from southern Slovakia to northern Slovenia, is the fact that they have lived there for quite a long time and thus show a strong influence of Hungarian culture on their own (cf. Halwachs 2004a: 1 and 2004b).

Living on the edge of society with their own social structure, the Roma repeatedly met with great misfortune. When Hungary was freed from Ottoman rule in 1688, it was decided that the Roma should be expelled from the country and executed if they did not comply (cf. Halwachs 2004b: 1f). Attempts to force them to assimilate continued in the reigns of Charles VI, Maria Theresa and Joseph II. In the second half of the $18^{\text {th }}$ century the Roma and Sinti were forced to settle on the outskirts of villages. They were forbidden to lead a nomadic existence and to use their own language, they were forced to marry non-Roma and their children were taken away to be raised in farming communities, etc. 
(Halwachs 2004b: 1f). Towards the end of the $19^{\text {th }}$ century, new Romany groups - the Lavora - settled on the shores of Lake Neusiedl (Gärtner-Horvath 1999: 9f).

Before 1939 there were around 7,000 to 8,000 Burgenland Roma, mainly living in their own houses or huts on the outskirts of villages or out in the country in central and southern Burgenland (cf. Thurner 1999: 25). Only around 10 percent of them survived the Nazi regime (cf. Gärtner-Horvath 1999: 8). As Halwachs points out, the oldest generation at that time, the group within any minority that maintains and passes on culture, fell victim to the genocide of the Nazi's extermination machinery (Halwachs 2004b: 2). And thus the Roma's socioculture was destroyed. Stigmatization and discrimination did not stop with the end of the Second World War. Many Roma left for the anonymity of eastern Austria's towns but those who stayed in Burgenland did not blend in with the majority population and continued to live on the edge of society (cf. Halwachs 2004b: 2):

\begin{abstract}
However, it should be distinguished between those who declare themselves as Roma and those who merely have Roma ancestry. The members of the second group, who do not declare themselves as Roma, have migrated from Burgenland to eastern Austrian cities, Vienna in particular, since the fifties.
\end{abstract}

It was not until the economically prosperous years of the 1960s and 1970s that some of them, at least, managed to break out of their social isolation, which led to an increase in self-esteem (Halwachs 2004: 3). In general, though, there is still a wide social gulf, which is partly caused by European-wide difficulties on the labour market. ${ }^{19}$ In order to combat this, projects have been set up in which Roma organizations from neighbouring countries cooperate with each other in order to take advantage of European Union grants. ${ }^{20}$

The Roma in Burgenland have been Austrian citizens since 1945. Their precise number is not recorded statistically in national censuses (Mayerhofer 1987: 53) but there are thought to be around 800 autochthonous Roma and Sinti living in Burgenland (cf. Ivancsics 2004: 69) and anywhere between 2,500 and 5,000 in Austria as a whole, according to their own estimates (cf. Halwachs 2004b: 2):

Today they are largely assimilated to the majority population, who in most cases do not know their ancestry. 
Therefore they cannot really be considered Austrian Roma which is the reason why they are excluded in the above mentioned number of the Austrian Roma population.

In 2000, the Committee of Ministers at the Council of Europe issued a recommendation that in countries where Roma live, Romany children should be given the opportunity to have schooling in their mother tongue. The European Charter for Regional or Minority Languages, CETS No. 148) dating from 1992, also covers non-territorial languages, including that of the Roma (Halwachs 2002: 99f). ${ }^{21}$

In March 1992, the Cultural Association of Austrian Roma and Sinti (Kulturverein der österreichischen Roma und Sinti) in Vienna and the Roma and Sinti - Association in Support of Gypsies (Roma und Sinti - Verein zur Förderung von Zigeunern) in Oberwart submitted a demand to the Austrian Federal Government that they be legally recognized as an ethnic group (cf. Rieger 2003: 234f). Once the necessary changes had been made to the Decree pertaining to the Ethnic Groups Advisory Board (Federal Law Gazette no. 895/1993) (Verordnung über die Volksgruppenbeiräte, BGBl. 895/1993), the Roma were formally recognized as the sixth autochthonous ethnic group in Austria on 16 December 1993 (cf. Sarközi 1999: 6; Rieger 2003: 237). Since 5 September 1995, they have had eight representatives on the Austrian government's Ethnic Groups Advisory Board (Sarközi 1999: 6).

The culture of the Roma and Sinti as well as their language with its many varied dialects are determined by an autonomous family-oriented social organization. Both have been passed on orally from generation to generation over the centuries (Rieger 2003: 230). There have never been any written records. Roman emerged from Old Indian Sanskrit and is related to modern-day Hindi languages. ${ }^{22}$

As part of a "Romani project" initiated by Dieter W. Halwachs at the University of Graz in 1993, work was started on codifying the language and illustrating how it could be taught. In the meantime the grammatical and lexical description has been completed and a spelling system devised but the project only covers the dialect spoken by lower class Roma in the vicinity of Oberwart in southern Burgenland (cf. http://romani.kfunigraz.ac.at/romani/index.en.shtml). The 
writing system of Burgenland Roman is based on German patterns, primarily to distinguish it from the Croatian and Hungarian minorities who use diacritics, and to disassociate the Burgenland Roma from other Roma groups (cf. Halwachs 2004b: 7). A sub-project, "Romlex", involved drawing up an online dictionary of many Romani variants (with their equivalents in German and English) while the "Rombase" project gave rise to a multilingual online encyclopaedia. ${ }^{23}$ Since 1996 an alphabet primer has been available as well as a trial version of a strip cartoon textbook. There are several computer games for children which help them to learn the language playfully (Gärtner-Horvath 1999: 11).

The language of the Roma exists in many different varieties whereby most young Roma only have passive knowledge of their language. As Halwachs points out, today's generation of grandparents (the over 50s) is generally bilingual and only in exceptional cases trilingual. Roman is the primary basilectal diatype and also functions as a mesolectal diatype in contacts with other Roma. Generally, Roma who do not know each other at all, or not very well, tend to use German almost exclusively. Depending on the immediate surroundings (Hungarian- or Croatian-speaking village), Hungarian and Croatian varieties are also used, but more usually as a mesolectal diatype than in the social "microcosmos" (cf. Halwachs 2004b: 9).

A 1994 survey on language use and attitudes towards language mostly revealed positive answers. Roma may have an inferiority complex but they also identify strongly with their language and endeavour to maintain it. Loyalty to their language is, in fact, high: around 90 percent of those asked wished to use it more intensely within the group and also wanted Roman to be used in kindergartens and schools. They would like to see newspapers, magazines and books published in Roman too. Classes organized by their associations, at primary level and in adult education, are already making use of initial work on codification of the language (cf. Halwachs 2004b: 10).

The first Roma associations in Burgenland were founded at the end of the 1980s (cf. Rieger 2003: 234). The Roma Association in Oberwart, for example, was set up in 1989, followed shortly after by an Advice Centre which deals with a wide range of social problems, organizes a homework club for Roma children of school age and provides work training programmes for young Roma. The Roma 
Association in Oberwart and the Cultural Association of Austrian Roma and Sinti in Vienna engage in political, cultural and social activities, all of which have led to an increase in the Roma's self-esteem (cf. Halwachs 2004b: 3). Sarközi's list mentions the following activities: social matters, living arrangements, the labour market, language, culture, information and documentation, lectures, research, symposia, public relations, publishing the newspapers Romano Kipo and Romano Centro, working together with other organizations and institutions, particularly political parties, the authorities and ministries, the church and the media, etc. (Sarközi 1999: 6).

Roman is also used occasionally in programmes produced by the Austrian Broadcasting Company's Burgenland studio.

\section{LINGUISTIC MINORITIES IN THE COUNTY OF GYÖR-MOSON-SOPRON IN WESTERN HUNGARY}

Hungarian constitutional reforms in 1989 represented a break with forty years of communist tradition. On 23 October 1989, the Republic of Hungary was declared an independent democratic state (von Bogday 1990: 150). These circumstances, the process of integration within Europe and the European Charter for Regional or Minority Languages of 1992 created a new set of conditions, generally improving the situation of ethnic minorities. ${ }^{24}$ The Protection of Minorites Act in Hungary lists the following thirteen minorities: Armenian, Bulgarian, German, Greek, Croatian, Polish, Romanian, Ruthenian, Serbian, Slovak, Slovene and Ukrainian (Deminger 2004: 20). These minorities are protected by the Nationalities Act of 1993 (No. LXXVII dating from 1993) ${ }^{25}$ including the right for personal autonomy and the founding of self-governing bodies (Deminger 2004: 20; Szakál/Rigó/Ferenczy 2004: 161).

\section{Ethnic Minorities in the County of Györ-Moson-Sopron}

The county of Győr-Moson-Sopron in northwestern Hungary lies at the interface of several languages and cultures. Alongside Hungarian speakers, there are three ethnic minorities: Germans, Croatians and Roma, all of whom have their own historical past, present and a different vision of the future. In the past the county administration was divided up into three independent units which could be subdivided into several smaller regions on historical grounds. The three parts 
of this county have always been treated as one socioeconomic unit (Szakál/Rigó/Ferenczy 2004: 148).

The minorities started to settle in this region after the Turks had been driven away in the $16^{\text {th }}$ and $17^{\text {th }}$ centuries. The ancestors of the Hungarian Germans came from Bavaria and Swabia, characteristically representing workers, the bourgeoisie and intelligentsia who lived in villages and towns alike. They formed the largest group. The Croatians arrived between 1524 and 1566, solely settling in villages as their social structures were dominated by agricultural workers. It is assumed that the Roma first arrived in the county in the mid-17 $7^{\text {th }}$ century although more precise documents and statistics on how they were distributed over the various villages do not exist (Szakál/Rigó/Ferenczy 2004: 149).

The assimilation of the minorities living in the county was accelerated after Burgenland became part of Austria and particularly after the German speakers were driven out on a large scale after the Second World War. This resulted in the younger generation switching over to Hungarian. Nowadays, German is taught as the second foreign language in schools (Szakál/Rigó/Ferenczy 2004: 157).

The Roma are faced with particularly worrying problems in connection with social matters, the labour market and education, whereas Hungarian Germans and Croatians have problems financing their cultural institutions. As Szakál/Rigó/Ferenczy point out, Roma have a strongly disturbed identity while the Croatian and German populations have a very strong double identity (Szakál/Rigó/Ferenczy 2004: 164). There is very little tension between the Croatians/Hungarian Germans and the Hungarians themselves, ${ }^{26}$ moreover there are very few contacts between the majority population and the Roma (Szakál/Rigó/Ferenczy 2004: 163).

In 1996, 425,470 people lived in the county of Győr-Moson-Sopron, subdivided ethnically into Hungarians $(400,770$ or 94.2 percent), Roma $(16,000$ or 3.8 percent $)^{27}$, Hungarian Germans $(6,000 \text { or } 1.4 \text { percent })^{28}$ and Croatians $(2,700$ or 0.6 percent). They are spread over 40 villages or towns in varying proportions (Szakál/Rigó/Ferenczy 2004: 151f).

The feeling of belonging to the ethnic group of Hungarian Germans relates almost entirely to their language while the Croatians assign their Catholicism an 
important role in maintaining their identity as a national minority. The Roma are subdivided linguistically and ethnically into three different groups. Roma who speak Hungarian as their mother tongue generally have high standards of education (doctors, teachers, musicians, etc.). The degree of assimilation is highest in this group and their sense of identity as Roma has virtually disappeared. It is, in fact, the lower social strata who uphold their ethnic identity. Another group consists of the so-called Beas. They speak an archaic Rumanian language which only exists orally so there are no written records on the history of the group in their own language although written references to them do exist. The third group, the so-called Olah or Vlax Roma in Raab/Györ, has a very strong sense of their own identity. Until well into the 1980s, the Olah lived in a closed community which enabled them to preserve their customs, traditions and language (Szakál/Rigó/Ferenczy 2004: 157-159).

Just like in Burgenland, life for Hungarian Roma has generally improved since the 1970s: living conditions are better, as is schooling, thanks to more consistent application of educational policies, although the situation is by no means ideal. As Daróczi points out (1988: 199f), only half of the Roma finish off compulsory schooling with a school-leaving examination at the age of 16 . Even if the 15 percent are added who gain their school-leaving qualifications as adults, this still means that four out of ten young Roma today do not have any basic qualifications. However, the Roma on both sides of the border have generally shown an increase in self-esteem over the last 20 to 25 years. Some of them more readily admit to being of Romany descent but are also very interested in giving the term Roma/gypsy a new meaning (cf. Daróczi 1988: 207).

In accordance with the Nationalities Act, self-governing bodies have been set up by the legally recognized ethnic minorities in Hungary, such as Cultural and Information Centres which are responsible for everything of importance for the minorities. Thus, the Hungarian German Cultural and Information Centre, as described on their homepage, is an institution which not only collects all information relating to the German minority in Hungary in connection with society, education, culture and the economy and makes it available to anybody who is interested in it, regardless of their nationality and whether they live in Hungary or not, but also draws public attention, directly and indirectly, to this information. The Centre also aims to encourage cooperation between 
institutions, communities and private individuals (cf. http://www.zentrum.hu/de). Self-governing bodies have been set up at local, county and state level over the last few years, although Germans and Croatians in the county of Györ-Moson-Sopron have criticized the fact that there is nothing at county level (Szakál/Rigó/Ferenczy 2004: 156).

\section{CONCLUSION}

The ethnic groups and smaller speech communities in the multicultural AlpineAdriatic region provide important links between European languages and cultures. Thanks to the opening up of borders and the fact that countries and regions are growing closer together in a common European cultural area, the situation of ethnic minorities in the Alpine-Adriatic region has generally improved. This is also true of Austria and western Hungary. Alongside existing minority laws and supportive measures at a national level, better conditions were created for small speech communities when the regulations laid down in the European Charter for Regional or Minority Languages (1992) came into effect. The promotion of cross-border cultural and economic cooperation by the European Union coupled with an improvement in the ethnic consciousness of members of minority language groups makes it possible for ethnic groups and almost forgotten linguistic communities in the Alpine-Adriatic region to find their way back to their own linguistic and cultural identity.

\section{REFERENCES}

Anderwald, Karl (2004), "Kärnten" (Kap. I. 4), in: Minderheiten (2004), pp. 178182.

Anderwald, Karl, Maria Novak-Tampusch (2004), "Kärnten", in: Minderheiten (2004), pp. 167-200.

Bakker, Peter (2003), Bibliography of Modern Romani Linguistics: Including a Guide to Romani Linguistics, comp. by Bakker, Peter, Yaron Matras. Amsterdam: Benjamins.

Bogday, Thomas von (1990), Grundzüge der Geschichte Ungarns, Darmstadt: Wissenschaftliche Buchgesellschaft.

Daróczi, Agnes (1988), "Die Zigeuner als Minderheit in Ungarn”, in: Bauböck, Rainer, Gerhard Baumgartner, Karin Pintér (Hgg.) (1988), ... und raus bist du! Ethnische Minderheiten in der Politik, Wien: Verlag für Gesellschaftskritik, pp. 198-208.

Deminger, Szilvia (2004), Spracherhalt und Sprachverlust in einer Sprachinselsituation. Sprache und Identität bei der deutschen Minderheit in Ungarn, Frankfurt am Main, Berlin etc.: Peter Lang. 
Domej, Theodor (1999), "Kärntner Slowenen. Eine Konfliktgeschichte (3). Die nationale Idee", in: Pilgram, Gerhard, Wilhelm Berger (Hgg.) (1999), Kärnten - unten durch ein UNIKUM-Wander-Reise-Lesebuch, Klagenfurt/Celovec: Drava, pp. 260-263.

Fräss-Ehrfeld, Claudia (2000), Geschichte Kärntens, Band 3/2, Kärnten 1918-1920. Abwehrkampf-Volksabstimmung. Identitätssuche, Klagenfurt: Heyn.

Fischer, Gero (1980), Das Slowenische in Kärnten. Bedingungen der sprachlichen Sozialisation. Eine Studie zur Sprachenpolitik, Wien: SIC.

Gärtner-Horvath, Emmerich (1999), "Die Situation der Roma im Burgenland", in: Klopčič, Vera, Miroslav Polzer (Hgg.) (1999), Wege zur Verbesserung der Lage der Roma in Mittel- und Osteuropa. Beiträge aus Österreich und Slowenien, Wien: Braumüller, pp. 9-12.

Grafenauer, Bogo (1984), “Jarniks 'Andeutungen' und ihr Stellenwert in der Forschung zur Germanisierung der Slowenen in Kärnten", in: Jarnik, Urban (Hg.) (1984), Andeutungen über Kärntens Germanisierung. Pripombe o germanizaciji Koroške. Mit einer Studie und Anmerkungen von Bogo Grafenauer. Spremna študija in opombe Bogo Grafenauer, Klagenfurt/Celovec: Drava, pp. 83113.

Grilj, Benjamin, Simon Hadler, Mathias Hammer (2006), "Verleugnung, Vergessen und Verdrängen. Das slowenische Kulturerbe in der Steiermark Eine Bestandsaufnahme", Signal, Winter/zima 2005/06, pp. 121-128.

Hafner, Stanislaus (1985), "Slowenische Volkssprache, die einseitige Zweisprachigkeit und Fragen der Sprachkultur in Kärnten", Incontri linguistici, 10 (1985), pp. 45-58.

Halwachs, Dieter W. (1999), "Romani in Österreich", in: Halwachs, Dieter W., Florian Menz (Hgg.) (1999), Die Sprache der Roma. Perspektiven der RomaniForschung in Österreich im interdisziplinären und internationalen Kontext, Klagenfurt: Drava.

Halwachs, Dieter W. (2002), "Romščina in njena zaščita v Evropi", in: Polzer, Miroslav, Liana Kalćina et al. (2002), Slovenija in evropski standardi varstva narodnih manjšin / Slovenia and European Standards for the Protection of National Minorities, Ljubljana: Informacijsko-dokumentacijski center Sveta Evrope pri NUK, Inštitut za narodnostna vprašanja, Avstrijski inštitut za vzhodno in jugovzhodno Evropo, pp. 95-100.

Heinschink, F. Mozes (2000), "Sprachen der Sinti und Roma", in: Ohnheiser, Ingeborg, Manfred Kienpointer, Helmut Kalb (Hgg.) (2000), Sprachen in Europa. Sprachsituation und Sprachpolitik in europäischen Ländern, Innsbruck: Institut für Sprachwissenschaft, pp. 177-190.

Info-Blatt (2004), "Die Roma in Österreich", Info-Blatt der Servicestelle politische Bildung, 4 (4. Dezember 2004).

Ivancsics, Martin (2004), "Burgenland", in: Minderheiten (2004), pp. 61-92.

Jodlbauer, Ralph (1996a), "Die Burgenländer Kroaten”, in: Hinderling, Robert, Ludwig M. Eichinger (Hgg.) (1996), Handbuch der mitteleuropäischen Sprachminderheiten, Tübingen: Narr, pp. 77-117. 
Jodlbauer, Ralph (1996b), "Die Kärntner Slowenen”, in: Hinderling, Robert, Ludwig M. Eichinger (Hgg.) (1996), Handbuch der mitteleuropäischen Sprachminderheiten, Tübingen: Narr, pp. 119-165.

Klemenčič, Vladimir (1994), "Narodne manjšine kot element politične, prostorske, socialne in ekonomske stvarnosti v Alpsko-jadranskem prostoru", in: Vencelj, Peter (Hg.) (1994), Arbeitsgemeinschaft von Kantonen, Ländern, Komitaten, Regionen und Republiken des Ostalpengebietes/Arbeitsgruppe Minderheiten, Manjšine v prostoru Alpe-Jadran: Bled, 21-22.10.1993. Zbornik referatov, 1-8, Ljubljana: Arbeitsgruppe Minderheiten der ARGE Alpen-Adria.

Klien, Rainer (1999), "Arbeitsmarktpolitische Auffangnetze für Roma”, in: Klopčič, Vera, Miroslav Polzer (Hgg.) (1999), pp. 75-78.

Klopčič, Vera, Miroslav Polzer (Hgg.) (1999), Wege zur Verbesserung der Lage der Roma in Mittel- und Osteuropa. Beiträge aus Österreich und Slowenien, Wien: Braumüller.

Koschat, Helene (1978), Die čakavische Mundart von Baumgarten im Burgenland, Wien: Verlag der Österreichischen Akademie der Wissenschaften.

Križman, Mirko (1996), "Die slowenische Minderheit in der Österreichischen Steiermark (Radkersburger Winkel)", in: Hinderling, Robert, Ludwig M. Eichinger (Hgg.) (1996), Handbuch der mitteleuropäischen Sprachminderheiten, Tübingen: Narr, pp. 167-183.

Križman, Mirko (1997), "Slowenisch im Radkersburger Winkel. Sprachliche und kulturelle Nachbarschaft, Interferenzen und Kulturgut", in: Stenner, Christian (1997), pp. 35-68.

Lukan, Walter (1979), "Die Slowenen in Kärnten von den Anfängen bis 1918", in: Deák, Ern (Hg.) (1979), Die Volksgruppen in Österreich, Wien, pp. 69-88.

Marti, Roland (2000), "Slavische Standardsprachen im Kontakt. Das Neben-, Mitund gegeneinander slavischer Standardsprachen", in: Zybatow, Lew N. (Hg.) (2000), Sprachwandel in der Slavia: die slavischen Sprachen an der Schwelle zum 21. Jahrhundert, Frankfurt am Main, Berlin etc.: Peter Lang, pp. 527-542.

Matras, Yaron (2002), Romani. A Linguistic Introduction, Cambridge: Cambridge University Press.

Maurer-Lausegger, Herta (1994a), "Situationally-motivated Speaking Habits Among Carinthian Slovenes", Slovene Studies, 15/1-2 (1994), pp. 87-99.

Maurer-Lausegger, Herta (1994b), "Sprache und Sprachgebrauch zweisprachiger Jugendlicher in Kärnten", Wiener Slawistischer Almanach, Sonderband, 37 (1994), pp. 219-231.

Maurer-Lausegger, Herta (2004), "The Diversity of Languages in the AlpineAdriatic Region I: Linguistic Minorities and Enclaves in Northern Italy",

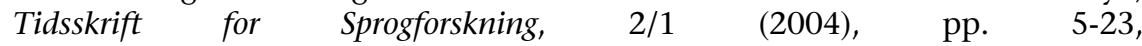
http://www.statsbiblioteket.dk/index.php/tfs/article/viewarticle/43

Maurer-Lausegger, Herta (2006a), "Sprachminderheiten im Alpen-Adria-Gebiet. Ihre Situation und ihr Stellenwert in der Europäischen Union", in: Borisova, Bagrelija, Vesela Belčeva et al. (eds.) (2006), Ezikovata politika na Evropejskija sjuz i evropejskoto universistetsko prostranstvo. Veliko T-rnovo, 5-7 oktomvri 2005 g. - The language policy of the EU and European university education, Veliko Turnovo 5-7 October 2005, P-rvi tom, vol. 1, Veliko Tarnovo: PIK, pp. 325-342. 
Maurer-Lausegger, Herta (2006b), "Deutsch-slowenische Zweisprachigkeit in Kärnten (Österreich)", in: Vliegen, Maurice (Hg.) (2006), Variation in Sprachtheorie und Spracherwerb. Akten des 39. Linguistischen Kolloquiums in Amsterdam 2004, Frankfurt am Main, Berlin etc.: Peter Lang, pp. 173-189.

Maurer-Lausegger, Herta (2008), “Audiovisual Documentation of Dialect in Bilingual Situations (Slovene/German)" in: Helin, Irmili (ed.) (2008), Dialect for all seasons: Cultural diversity as tool and directive for dialect researchers and translaters, Münster: Nodus, pp. 65-76, www.kwfilm.com.

Mayerhofer, Claudia (1987), Dorfzigeuner. Kultur und Geschichte der BurgenlandRoma von der Ersten Republik bis zur Gegenwart, Wien: Picus Verlag.

Minderheiten (1990), Die Minderheiten im Alpen-Adria-Raum, deutsche Fassung, Klagenfurt, pp. 253-264.

Minderheiten (2004), Minderheiten und grenzüberschreitende Zusammenarbeit im Alpen-Adria-Raum, deutsche Fassung,. hrsg. von Böckler, Stefan, Trient: Arbeitsgemeinschaft Alpen-Adria, Autonome Region Trentino-Südtirol.

Moguš, Milan (1977), Čakavsko narječje. Fonologija, Zagreb: Školska knjiga.

Moritsch, Andreas (1995), "Das Windische. Eine nationale Hilfsideologie", in: Moritsch, Andreas (Hg.) (1995), Problemfelder der Geschichte und Geschichtsschreibung der Kärntner Slovenen - Problemska polja zgodovine in zgodovinopisja koroških Slovencev, Klagenfurt, Ljubljana etc.: Hermagoras/Mohorjeva, pp. 15-31.

Moritsch, Andreas (Hg.) (2001), Alpen-Adria. Zur Geschichte einer Region, redaktionelle Betreuung: Harald Krahwinkler, Klagenfurt, Ljubljana etc.: Hermagoras/Mohorjeva.

Neweklowsky, Gerhard (1978), Die kroatischen Dialekte des Burgenlandes und der angrenzenden Gebiete, Wien: Verlag der Österreichischen Akademie der Wissenschaften.

Neweklowsky, Gerhard (2006), "Die kroatische Sprache im Burgenland heute", Studia Slavica Academiae Scientiarum Hungaricae, 51/1-2 (2006), Separatum, 13 pp.

Peco, Asim (1991), Pregled srpskohrvatskih dijalekata, Beograd: Naučna knjiga.

Reiterer, Albert F. (1990), Zwischen Wohlstand und Identität. Ethnische Minderheiten und Modernisierung: Die Burgenland-Kroaten, Wien: VWGÖ.

Reiterer, Albert F. (1996), Kärntner Slowenen: Minderheit oder Elite? Neuere Tendenzen der ethnischen Arbeitsteilung, Klagenfurt: Drava.

Reiterer, Albert F. (2004), "Die Kärntner Slowenen” (Kap. I.1; Kap. I.2; Kap. I.3 z. T.; Kap. II.1), in: Minderheiten (2004), pp. 172-178, 187-191.

Rektorenkonferenz (Hgg.) (1989), Bericht der Arbeitsgruppe, Lage und Perspektiven der Volksgruppen in Österreich. Mit einem statistischen Ergänzungsheft, Österreichische Rektorenkonferenz, Wien: Böhlau.

Rieger, Barbara (2003), Roma und Sinti in Österreich nach 1945. Die Ausgrenzung einer Minderheit als gesellschaftlicher Prozeß, Frankfurt am Main, Berlin etc.: Peter Lang. 
Robak, Fritz (1985), Kroaten im Burgenland. Eine Dokumentation, Wien, München etc.: Europaverlag.

Rumpler, Helmut (2001), "Verlorene Geschichte. Der Kampf um die politische Gestaltung des Alpen-Adria-Raumes", in: Moritsch, Andreas (2001), pp. 517569.

Sarközi, Rudolf (1999), "Lage und Organisation der Roma und Sinti in Österreich", in: Klopčič, Vera, Miroslav Polzer (1999), pp. 5-8.

Schrammel, Barbara (ed.) (2005): General and applied Romani linguistics. Proceedings from the $6^{\text {th }}$ International Conference on Romani Linguistics, München: Lincom Europa.

Stenner, Christian (1997), Slowenische Steiermark. Verdrängte Minderheit in Österreichs Südosten, Wien, Köln etc.: Böhlau.

Szakál, Gyula, Rozália Rigó, Zoltán Ferenczy (2004), “Győr-Moson-Sopron”, in: Minderheiten (2004), pp.145-166.

Szucsich, Luka (2000), "Das Burgenlandkroatische: Sprachwandel, Sprachverfall, Sprachverschiebung und Sprachassimilation", in: Zybatow, Lew N. (Hg.) (2000), Sprachwandel in der Slavia: die slavischen Sprachen an der Schwelle zum 21. Jahrhundert, Frankfurt am Main, Berlin etc.: Peter Lang, pp. 853-875.

Thurner, Erika (1988), “'Zigeunerleben' in Österreich - Rechtliche und soziale Stellung von Sinti und Roma nach 1945", in: Bauböck, Rainer, Gerhard Baumgartner, Bernhard Perchinig, Karin Pintér (Hgg.) (1988): ... und raus bist du! Ethnische Minderheiten in der Politik, Wien: Verlag für Gesellschaftskritik, pp. 57-67.

Thurner, Erika (1999), "Von einer sozialen Randgruppe zu einer anerkannten Minderheit", in: Halwachs, Dieter W., Florian Menz (Hgg.) (1999), Die Sprache der Roma. Perspektiven der Romani-Forschung in Österreich im interdisziplinären und internationalen Kontext, Klagenfurt: Drava, pp. 19-34.

Valentin, Hellwig (2005), Der Sonderfall. Kärntner Zeitgeschichte 1918-2005, Klagenfurt. Mohorjeva/Hermagoras.

Volksgruppenreport (1997), Österreichisches Volksgruppenzentrum. Volksgruppenreport 1997, Wien: Österreichisches Volksgruppenzentrum.

Volksgruppenreport (1998), Österreichisches Volksgruppenzentrum. Volksgruppenreport 1998, Wien: Österreichisches Volksgruppenzentrum.

Volksgruppenreport (2001), Österreichisches Volksgruppenzentrum. Volksgruppenreport 2001. Zur Lage der ethnischen Minderheiten in der Republik Österreich. NGO-report, Minderheiten in Österreich, Wien: Österreichisches Volksgruppenzentrum.

Völkl, Darinka (2000), "Südslawische Minderheiten in Österreich", in: Ohnheiser, Ingeborg, Manfred Kienpointer, Helmut Kalb (Hgg.) (2000), Sprachen in Europa. Sprachsituation und Sprachpolitik in europäischen Ländern, Innsbruck: Institut für Sprachwissenschaft, pp. 59-70.

Wöbking, Konstantin (2000), “Ungarisch - eine uralische Sprache in Mitteleuropa", in: Ohnheiser, Ingeborg, Manfred Kienpointer, Helmut Kalb (Hgg.) (2000), Sprachen in Europa. Sprachsituation und Sprachpolitik in europäischen Ländern, Innsbruck: Institut für Sprachwissenschaft, pp. 77-94. 
Zwitter, Fran (1979), Die Kärntner Frage, Klagenfurt/Celovec: Slovenski znanstveni inštitut/Slowenisches wissenschaftliches Institut.

\section{ONLINE}

Baumgartner, Gerhard, Florian Freund (2007), Roma policies in Austria. http://www.kv-roma.at/FRAMES/Romapolitik/Roma\%20English\%202007.pdf Accessed 2008-02-27

Halwachs, Dieter W. (2004a), Roma and Romani in Austria, in: http://romani.kfunigraz.ac.at/romani/download/files/ling rom at e.pdf Accessed 2006-12-20

Halwachs, Dieter W. (2004b), Burgenland-Roma, in: http://romani.kfunigraz.ac.at/romani/download/files/ling rom burg d.pdf Accessed 2006-12-20

Matras, Yaron (2005), The classification of Romani dialects: A geographichistorical perspective, in:

http://romani.humanities.manchester.ac.uk/downloads/2/Matras_classificati on.pdf

Accessed 2008-02-25

http://conventions.coe.int/Treaty/Commun/ListeDeclarations.asp?NT=148\&CM $=\$ D F=\& C L=E N G \& V L=1$

Accessed 2008-02-26

http://conventions.coe.int/Treaty/en/Treaties/Word/148.doc

Accessed 2006-12-28

http://de.wikipedia.org/wiki/Burgenlandkroaten

Accessed 2008-12-08

http://romani.kfunigraz.at/romani

Accessed 2006-12-28 
http://romani.kfunigraz.at/romani/index.en.shtml

Accessed 2006-12-20

http://romani.kfunigraz.at/rombase

Accessed 2006-12-28

http://romani.kfunigraz.at/romlex

Accessed 2006-12-28

http://volksgruppen.orf.at/kroatenungarn

Accessed: 2006-12-20

http://volksgruppen.orf.at/slowenen

Accessed: 2006-12-20

http://www.austria.gv.at/2004/4/16/volksgruppengesetz.pdf

Accessed: 2006-12-15

http://www.bmeia.gv.at/botschaft/laibach/bilateralebeziehungen/wirtschaft.html

Accessed: 2008-01-22

http://www.demokratiezentrum.org

Accessed: 2008-12-09

http://www.elnet.at

Accessed: 2006-12-15

http://www.hrvatskicentar.at

Accessed: 2006-12-15

http://www.hrvatskicentar.at/deutsch/default.htm

Accessed: 2006-12-11

http://www.kkz.at 
The Diversity of Languages in the Alpine-Adriatic ReGion II

Accessed: 2006-12-15

http://www.kv-roma.at

Accessed: 2008-02-26

http://www.minelres.lv/NationalLegislation/Hungary/Hungary_Minorities_Engli sh.htm

Accessed: 2008-02-26

http://www.nsks.at

Accessed 2006-12-26

http://www.nsks.at/aktuelles.php

Accessed 2006-12-26

http://www.nsks.at/recht.php

Accessed: 2006-12-15]

http://www.pavelhaus.at

Accessed: 2006-12-15

http://www.pavelhaus.at/publikationen/signal00_deutsch/signal00_02.htm

Accessed: 2006-12-15

http://www.skupnost.at

Accessed: 2006-12-15

http://www.skupnost.at/1de/statut/fs statut.htm

Accessed: 2006-12-15

http://www.slo.at

Accessed: 2006-12-18

http://www.statistik.at 
Accessed 2006-12-18

http://www.umiz.at

Accessed 2006-12-28

http://www.volksgruppenbuero.at

Accessed: 2006-12-15

http://www.volksgruppenbuero.at/services/C4

Accessed: 2006-12-15

\section{http://www.zigh.at}

Accessed: 2005-12-18

http://www.zentrum.hu/de

Accessed: 2006-12-12

\section{NOTES}

1 This is part two in a series of three articles dealing with linguistic minorities in the Alpine-Adriatic region, starting with Maurer-Lausegger, Herta "The diversity of languages in the Alpine-Adriatic region I: Linguistic minorities and enclaves in northern Italy", Tidsskrift for Sprogforskning, 2, 1 (2004), pp. 5-23. The second part was presented in much shorter form at Tokyo University of Foreign Studies in September 2001. The third article will deal with ethnic minorities in Slovenia and Croatia.

2 Our concept of minorities in the "Alpine-Adriatic region" is based on the geographic area covered by the Alpine-Adriatic Association (cf. Minderheiten 2004).

3 Cf. Klemenčič (1994: 6); see Moritsch (2001) for more information.

4 The Alpine-Adriatic Association oversees cross-border cooperation in the region at an economic, social, cultural and political level (cf. Minderheiten 2004) while the European Union's programmes facilitate many forms of bilateral and multilateral cooperation between regions and countries. Austria, for example, is the most important foreign investor in Slovenia with the Austrian share of total foreign direct investments in Slovenia adding up to 29.9 percent. Cf. http://www.bmeia.gv.at/botschaft/laibach/bilaterale-beziehungen/wirtschaft.html

5 In contrast, the Czech and Slovak minorities are not concentrated in specific areas, although most of them live in Vienna and Lower Austria (in the Marchfeld and Tullnerfeld regions). However, as they are not in the Alpine-Adriatic region as defined in footnote 2 , they will not be dealt with in this paper.

6 For more information on the current legal situation of the Carinthian Slovenes see Anderwald/Novak-Trampusch (2004); http://www.nsks.at/recht.php. Downloads are available of legal texts, Article 7 of the Austrian State Treaty of 1955, The Ethnic 
Groups Act of 1976, Slovene as an official language (1977), topographical terminology and inscriptions (decree issued by the Federal Government, 1977), Carinthian Kindergarten Funding Law (K KGFG 2001)

7 Cf. http://www.austria.gv.at/2004/4/16/volksgruppengesetz.pdf $\quad$ For a detailed description of individual rights of Austrian minorities see: Volksgruppenreport (2001); http://www.demokratiezentrum.org

8 Cf. Maurer-Lausegger (2006b: 174f), Fräss-Ehrfeld (2000: 26). For more details on this issue see Lukan (1979).

9 A solid academic presentation of Carinthian history between 1918 and 2004 is given in Valentin's monograph (2005).

10 Cf. http://www.koroska.at/service.php?id=C0 61_13. All activities carried out by the Office for Ethnic Minorities are listed online and their information brochure can be downloaded at http://www.koroska.at.

11 Cf. Reiterer (1996). The problems of being bilingual in Carinthia will be dealt with in more detail in a separate study.

12 Cf. http://www.statistik.at; for more information on the numbers of German- and Slovene-speakers in southern and lower Styria from 1830 to 1991, see Klemenčič (1997).

13 For more details, see http://www.pavelhaus.at/; http://www.pavelhaus.at/ publikationen/signal00_deutsch/signal00_02.htm.

14 The Cakavian dialect, a form of Croatian, is spoken on the Dalmatian and Quarner islands, in central Istria, in areas along the Dalmatian coast and in some central parts of Croatia. Modern-day borders between the dialects spoken inland are quite fuzzy for historical reasons due to migration and interdialectal entanglement (cf. Peco 1991: 213ff; Moguš 1977). The Cakavian dialect plays an important role in the historical grammars of Croatian and Slovene as well as in comparative Slavic linguistics.

15 Cf. http://www.statistik.at; Szucsich (2000: 853). The total number of Burgenland Croatians living in Austria, western Hungary, Slovakia, the Czech Republic and elsewhere is estimated at around 70,000 people (http://de.wikipedia.org/wiki/Burgenlandkroaten).

16 Cf. Szucsich (2000: 874); see Jodlbauer (1996a: 91-110) for more information.

17 The Finno-Ugric languages are divided into two branches: a Ugric branch with Hungarian, together with the Ob-Ugric languages (Mansi and Khanty) which are dying out, and a Finnish-Permic branch with the more closely related Baltic-Finnish languages which include Finnish, Estonian and numerous micro languages, often with only a few speakers. Out of all the languages in the Finno-Ugric family, Hungarian is the language spoken by the most people (Wöbking 2000: 78).

18 More details on the activities, institutions, organizations and media of the Austrian Hungarians are provided by the Hungarian Media and Information Centre http://www.umiz.

19 For more details on labour market policies affecting the Roma see Klien (1999); see Klopčič/Polzer (1999) for more information.

20 Cf. Gärtner-Horvath (1999: 11f). The history of the Roma over the last 1000 years is told in a permanent exhibition at the Documentation and Information Centre of the Cultural Association of Austrian Roma (cf. Sarközi 1999: 6).

21 Cf. List of declarations made with respect to treaty No. 148: Declaration contained in the instrument of ratification deposited on 28 June 2001 - Or. Engl./Aus: "Austria declares that minority languages within the meaning of the Charter in the Republic of Austria shall be the Burgenlandcroatian, the Slovenian, the Hungarian, the Czech, the Slovakian languages and the Romany language of the Austrian Roma minority. [...]. 
Herta Maurer-LausegGer

Part II of the Charter shall be applied to the Burgenlandcroatian, the Slovenian, the Hungarian, the Czech, the Slovakian languages and the Romany language of the Austrian Roma minority upon its entry into force in the Republic of Austria. The objectives and principles laid down in Article 7 of the Charter shall form the bases with regard to these languages. At the same time, Austrian law and established administrative practice thus meet individual requirements laid down in Part III of the Charter." http://conventions.coe.int/Treaty/Commun/ListeDeclarations.asp?NT=148\& $\mathrm{CM}=\& \mathrm{DF}=\& \mathrm{CL}=\mathrm{ENG \& VL=1}$. For more detailed information on Austrian policies on the Roma see: http://www.kv-roma.at/ and Baumgartner/Freund (2007): http://www.kvroma.at/FRAMES/Romapolitik/Roma\%20Englisch\%202007.pdf; on the recognition of Roma and Sinti as an ethnic group in 1993 and the relevance of the Ethnic Groups Acts, see Rieger (2003: 230-242).

22 The academic world is paying more and more attention to the language of the Roma. See Halwachs/Menz (1999), Matras (2002), Matras (2005), Bakker (2003), amongst others.

23 See also the detailed bibliography in Halwachs (2004a, 2004b) and under http://romani.kfunigraz.ac.at/romani/ling/projectroman.de.shtml; http://www-gewiuni-graz.at/rombase, http://www.gewi.uni-graz.at/romani.

24 See Charter for Regional or Minority Languages (ETS No. 148). Decision of the Parliament No. 35/1995 (IV.7):

On the ratification of the European Charter on Regional or Minority Languages and on the undertakings taken by the Republic of Hungary in conformity with its Article 2, litt. 2, The Parliament, on a proposition from the Government:

1. Ratifies the European Charter on Regional or Minority Languages, elaborated on 5 November 1992, which text is reproduced in Appendix No. 1.

2. Agrees that the undertakings taken in conformity with Article 2, litt. 2, of the Charter reproduced in Appendix No.

2 extend to the Croatian, German, Romanian, Serbian, Slovakian, Slovenian languages. [...]

http://conventions.coe.int/Treaty/en/Treaties/Word/148.doc

http://www.minelres.lv/NationalLegislation/Hungary/Hungary_Minorities_English. $\underline{\mathrm{htm}}$

25 See Act LXXVII of 1993 on the Rights of National and Ethnic Minorities:

http://www.minelres.lv/NationalLegislation/Hungary/Hungary_Minorities_English. $\underline{\mathrm{htm}}$

26 Cf. Szakál/Rigó/Ferenczy (2004: 163). More details on the activities, institutions, organizations and media of the Hungarian Germans are provided by the Hungarian German Cultural and Information Centre - http://zentrum.hu/de.

27 A sociological survey carried out by the Hungarian Academy of Sciences came up with the figure of an estimated 320,000 Roma in Hungary in 1971 (cf. Daróczi 1988: 198).

28 Minority organizations estimate that the number of German Hungarians in Hungary is in the region of 200,000 to 220,000 people (cf. Deminger 2004: 20f). 


\section{APPENDIX: MAPS}

\section{Map 1: Ethnic minorities in Austria}

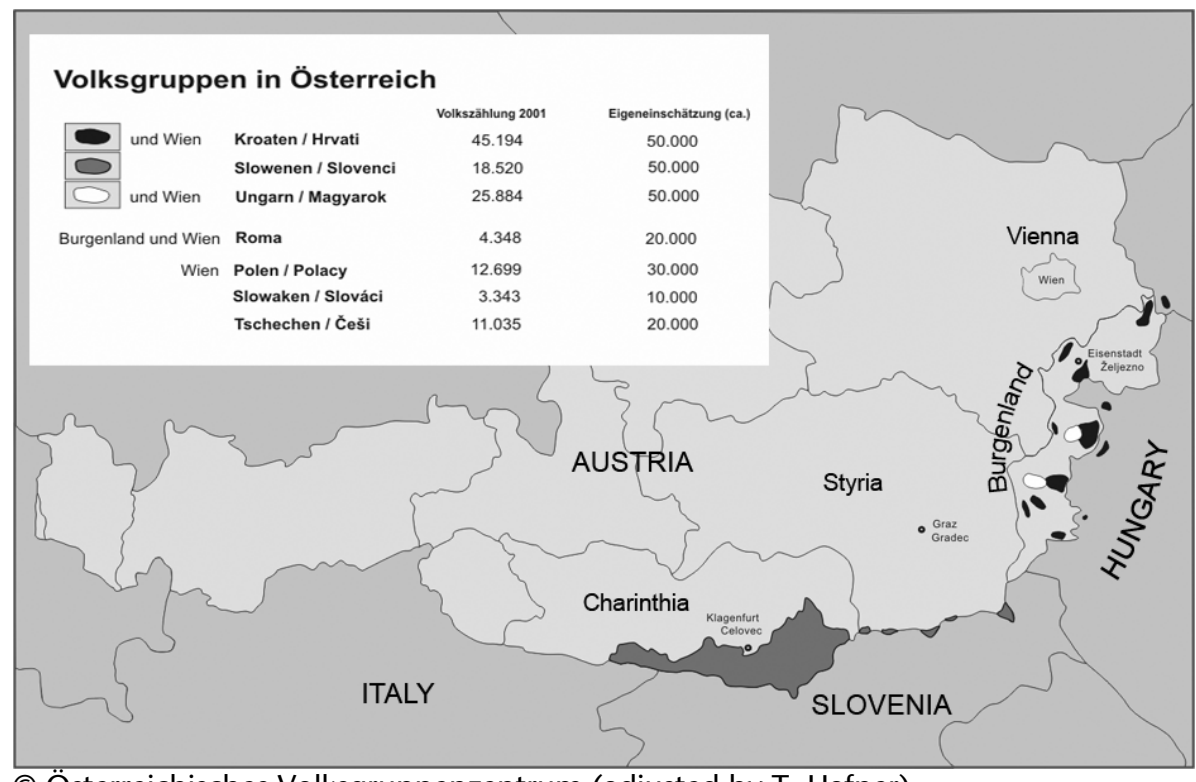

(C) Österreichisches Volksgruppenzentrum (adjusted by T. Hafner)

Volkszählung 2001 - 2001 Census

Eigeneinschätzung - Estimated

Kroaten/Hrvati - Croats

Slowenen/Slovenci - Slovenes

Ungarn/Magyarok - Hungarians

Roma - Roma

Polen/Polacy - Poles

Slowaken/Slováci - Slovacs

Tschechen/ eši - Czechs 
Map 2: The Carinthian Slovenes (Austria)

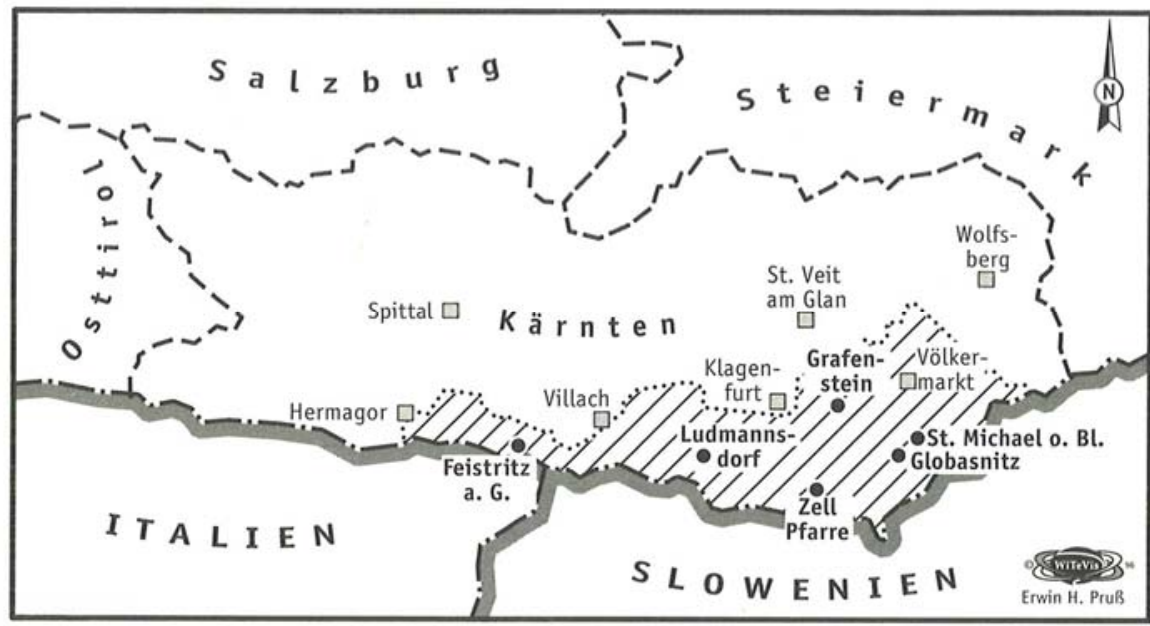

(Jodlbauer 1996b)

Map 3: The Styrian Slovenes (Austria)

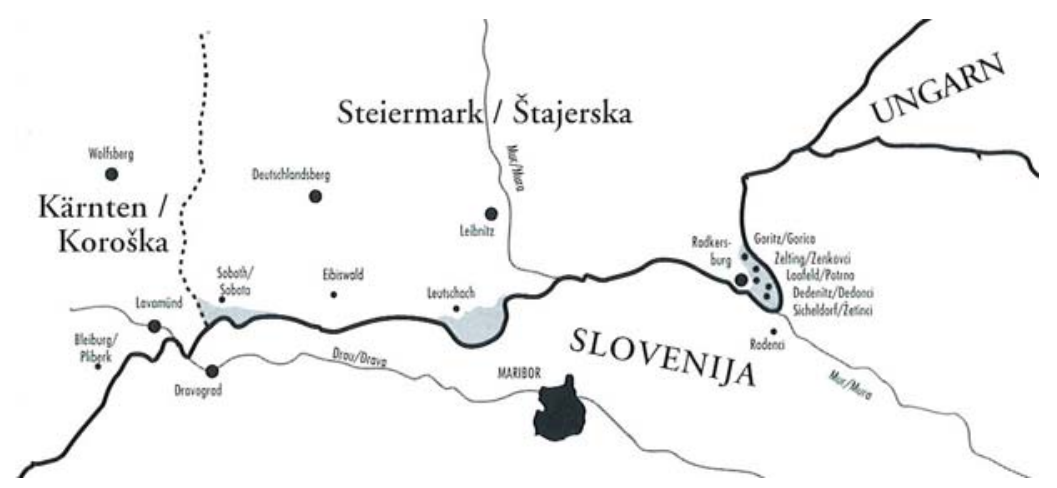

(Volksgruppenreport 1997: 99) 
The Diversity of Languages in the Alpine-Adriatic ReGion II

Map 4: The Burgenland Croatioans (Austria)

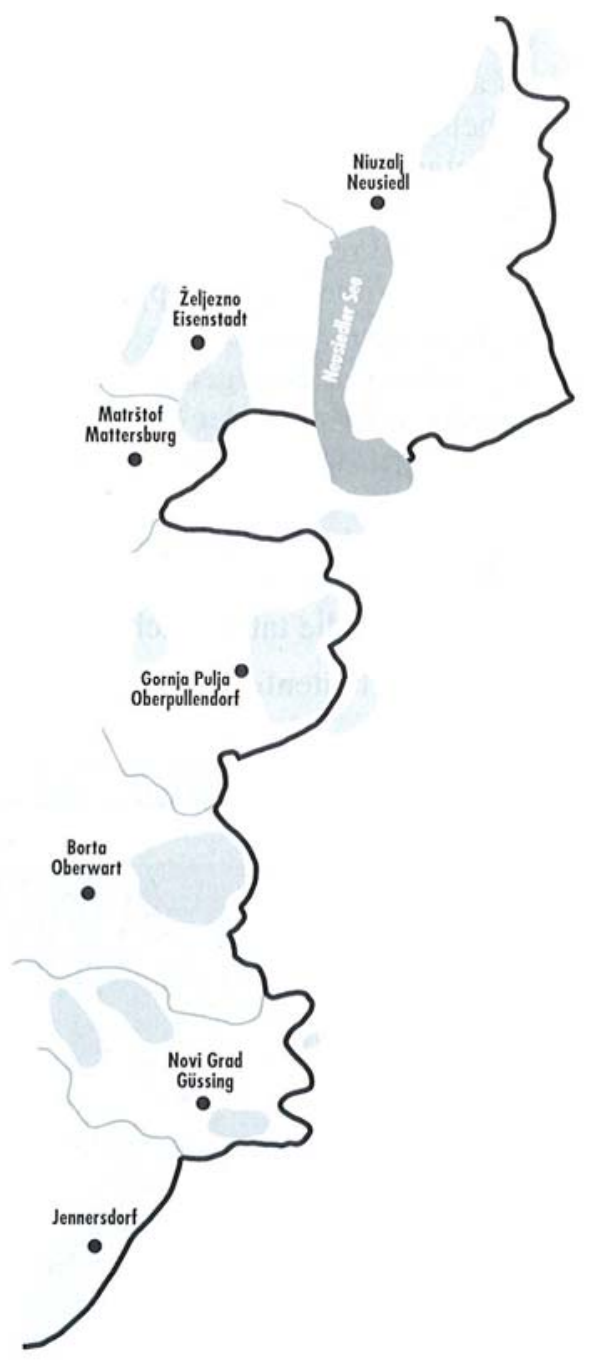

(Volksgruppenreport 1997: 99) 
Herta Maurer-LausegGer

Map 5: The Hungarians in Burgenland (Austria)

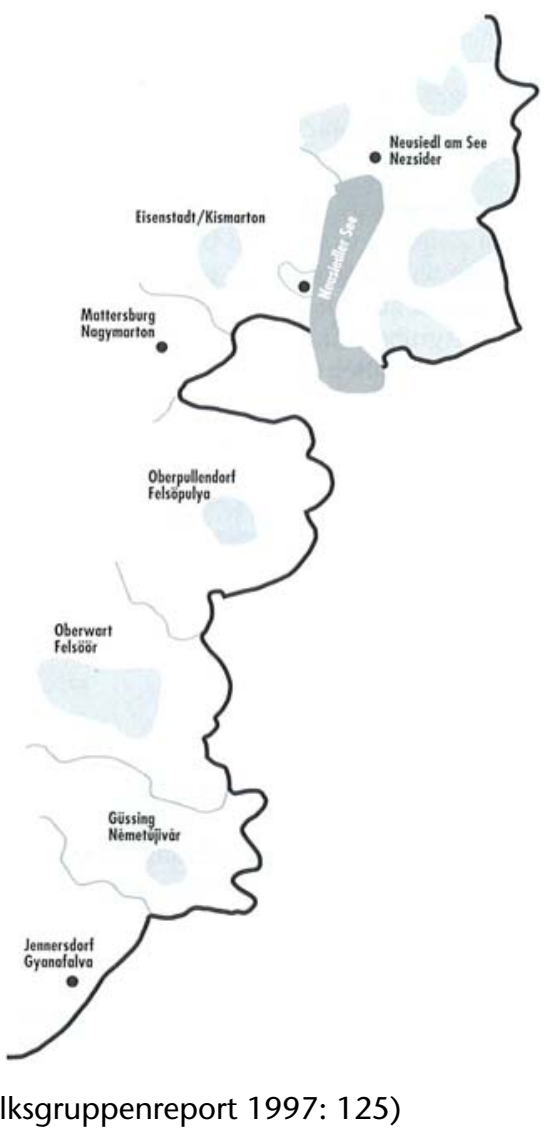


Map 6: The Roma in Burgenland (Austria)

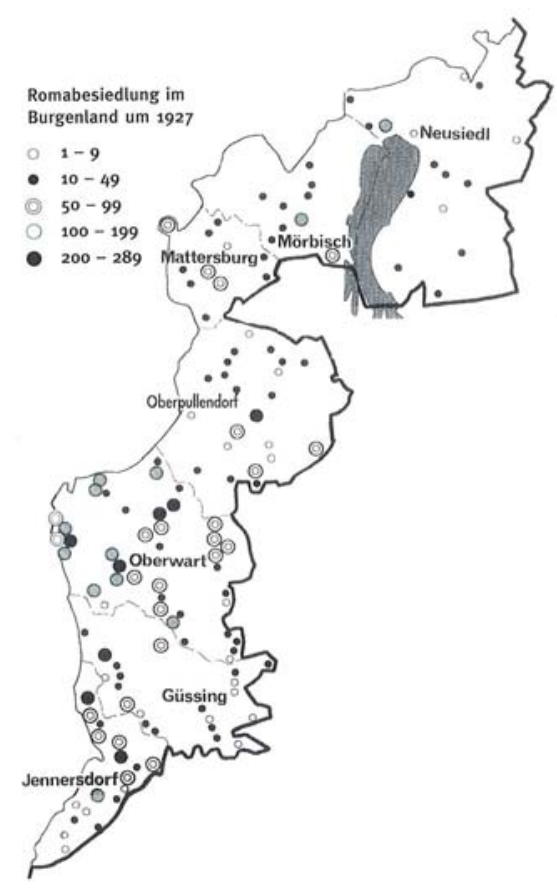

Roma settlements in Burgenland at about 1927 (Volksgruppenreport 1997: 149).

Map 7: The county of Győr-Moson-Sopron (northwestern Hungary)

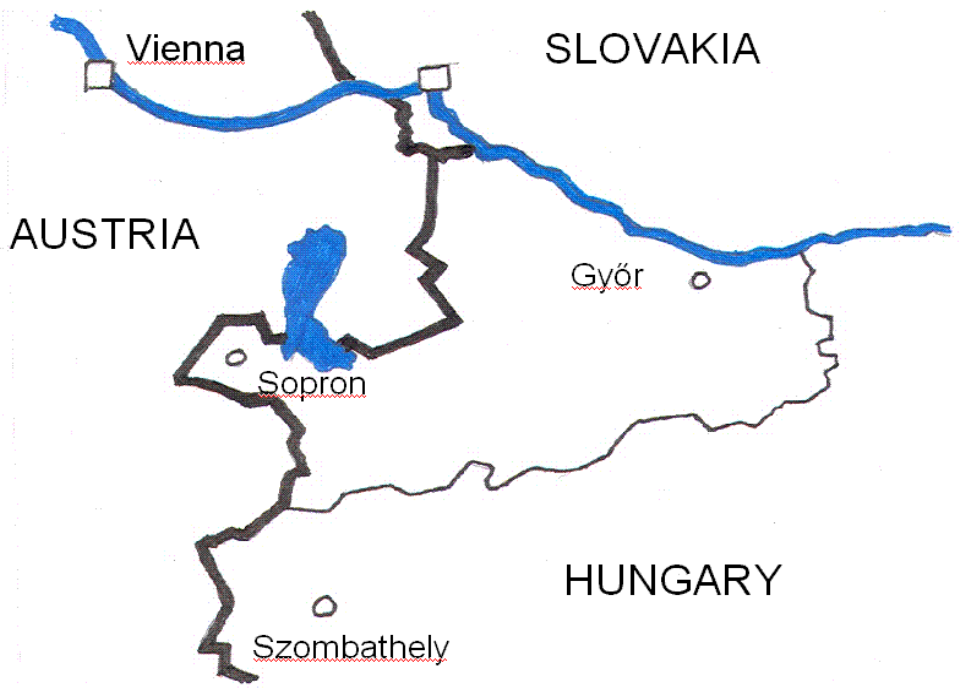

(T. Plessnig) 